\title{
Biodegradation of Polyethoxylated Nonylphenols
}

\author{
Yassellis Ruiz, ${ }^{1,2}$ Luis Medina, ${ }^{1}$ Margarita Borusiak, ${ }^{2}$ Nairalith Ramos, ${ }^{1}$ \\ Gilberto Pinto, ${ }^{3}$ and Oscar Valbuena ${ }^{1}$ \\ ${ }^{1}$ Centro de Investigaciones Microbiológicas Aplicadas (CIMA), Facultad de Ciencias de la Salud, Universidad de Carabobo, \\ Valencia 2005, Venezuela \\ ${ }^{2}$ Centro de Investigaciones Químicas (CIQ), Facultad de Ingeniería, Universidad de Carabobo, Valencia 2005, Venezuela \\ ${ }^{3}$ Departamento de Química, Facultad de Ciencias y Tecnología (FACYT), Universidad de Carabobo, Bárbula 2001, \\ Naguanagua 2005, Carabobo, Venezuela
}

Correspondence should be addressed to Yassellis Ruiz; yjruiz1977@gmail.com

Received 14 May 2013; Accepted 4 June 2013

Academic Editors: P. Di Martino and T. P. West

Copyright (C) 2013 Yassellis Ruiz et al. This is an open access article distributed under the Creative Commons Attribution License, which permits unrestricted use, distribution, and reproduction in any medium, provided the original work is properly cited.

\begin{abstract}
Polyethoxylated nonylphenols, with different ethoxylation degrees $\left(\mathrm{NPEO}_{x}\right)$, are incorporated into many commercial and industrial products such as detergents, domestic disinfectants, emulsifiers, cosmetics, and pesticides. However, the toxic effects exerted by their degradation products, which are persistent in natural environments, have been demonstrated in several animal and invertebrate aquatic species. Therefore, it seems appropriate to look for indigenous bacteria capable of degrading native $\mathrm{NPEO}_{x}$ and its derivatives. In this paper, the isolation of five bacterial strains, capable of using $\mathrm{NPEO}_{15}$, as unique carbon source, is described. The most efficient $\mathrm{NPEO}_{15}$ degrader bacterial strains were identified as Pseudomonas fluorescens (strain Yas2) and Klebsiella pneumoniae (strain Yas1). Maximal growth rates were reached at $\mathrm{pH} 8,27^{\circ} \mathrm{C}$ in a $5 \% \mathrm{NPEO}_{15}$ medium. The $\mathrm{NPEO}_{15}$ degradation extension, followed by viscometry assays, reached $65 \%$ after $54.5 \mathrm{~h}$ and $134 \mathrm{~h}$ incubation times, while the COD values decreased by $95 \%$ and $85 \%$ after $24 \mathrm{~h}$ for the Yasl and Yas 2 systems, respectively. The BOD was reduced by $99 \%$ and $99.9 \%$ levels in $24 \mathrm{~h}$ and $48 \mathrm{~h}$ incubations. The viscosity data indicated that the $\mathrm{NPEO}_{15}$ biodegradation by Yas 2 follows first-order kinetics. Kinetic rate constant $(k)$ and half life time $(\tau)$ for this biotransformation were estimated to be $0.0072 \mathrm{~h}^{-1}$ and $96.3 \mathrm{~h}$, respectively.
\end{abstract}

\section{Introduction}

Alkyl polyethoxylates (APEO), widely used as industrial and domestic surfactants, are added to a variety of products such as dispersants, emulsifiers, detergents, dyes, antioxidants, pesticides, spermicides, and cosmetics [1-4]. Most of these compounds including nonylphenol polyethoxylates $\left(\mathrm{NPEO}_{x}\right)$ are incorporated to aqueous solutions, and after being used, they are discharged in industrial or municipal water waste and eventually enter water treatment plants $[5,6]$. Due to their persistency at low temperatures $\mathrm{NPEO}_{x}$ remain in the environment and could be bioaccumulated, which is harmful to animals, humans, and other biological aquatic species [7-10], as its degradation products are more toxic than the original molecule $[1,3,8,11-13]$. The toxic effects exerted by $\mathrm{NPEO}_{x}$ and its degradation products include reduction of spermatozoid number, increase of testicular cancer, and feminism in aquatic male species $[7,8,14,15]$. The highly ethoxylated $\mathrm{NPEO}_{x}$ compounds lack estrogenic activity, whereas the low ethoxylated ones, included nonylphenol, which arise from nonylphenol ethoxylates by degradation in natural environments, do affect fishes, amphibians, birds, mammalians, invertebrates species such as crustaceans, mollusks, algae, yeast, and plants [3, 16-19]. These compounds also negatively affect microbial biomass growth by competitive inhibition mechanisms when the biomass is not acclimated [20]. Apparently, the estrogenic activity is induced because nonylphenol mimics the structure of the female sexual hormones, the estrogens $[5,21,22]$. Thus, nonylphenol and ethoxylated alkylphenols have been classified as pseudoestrogens and endocrine disrupters because of the harmful effects on the endocrine systems, the reproductive cycles, and other vital functions in humans and other animal species $[4,6,13,23,24]$. 
$\mathrm{NPEO}_{x}$ degradation occurs through several pathways: (I) Cleavage of the ether bonds with the generation of alkyl-phenol derivatives with shorter ethoxylated chains, which yields mono- and diethylated compounds $\left(\mathrm{NPEO}_{1}\right.$ and $\mathrm{NPEO}_{2}$ ) that could further be carboxylated to form ethoxyacetic and acetic nonylphenol acids [11, 25-27]. (II) $\omega$-Carboxylation of the ethoxylated chain, yielding different polyethoxylated derivatives, being the most abundant the diethoxylated species $\left(\mathrm{NPEO}_{2} \mathrm{C}\right)$; simultaneously, it is possible that the oxidation of the nonyl chain generates dicarboxylic compounds $\left(\mathrm{CNPEO}_{1} \mathrm{C}\right)$, without production of nonylphenol [12]. (III) Simultaneous shortening of the ethoxylated and alkylic chains to produce propyl and heptyl diethoxylated compounds [2] and (IV) oxidation of the polyethoxylated chain, without any shortening, to yield the corresponding carboxylic acids $[27,28]$. Besides, it has been reported that the initial step in the $\mathrm{NPEO}_{x}$ degradation occurs on the ethoxylated moiety of the molecule, followed by further attack on the aromatic nonylphenol ring [29].

The degradation of the aromatic ring occurs under aerobic conditions yielding several soluble metabolites which are finally degraded to $\mathrm{CO}_{2}$ [30]; the kinetic order of the reaction corresponds to a first-order process $[31,32]$. In anaerobiosis, Pseudomonas putida degraded $\mathrm{NPEO}_{x}$, with different length chains $\left(x=6,9\right.$ and 20), yielding as a final product $\mathrm{NPEO}_{2}$, no carboxylic acids were detected [8].

Sphingomonas xenophaga was able to cleave the aliphatic nonyl chain, bound to the phenol, depending on a specific branching pattern [5]; only the para isomer was degraded [23].

Finally, degradation of $\mathrm{NPEO}_{x}$ is carried out by several bacterial genera: Pseudomonas, Sphingomonas, Cupriavidus, Ralstonia, Achromobacter, Staphylococcus, Ochrobactrum, castellania, Variovorax, Bacillus, and Psychrobacter [25, 27, 28, 33-35].

Due to the negative effects of $\mathrm{NPEO}_{x}$ on animals and the natural environment, its use for manufacturing domestic detergents has been banned, and their industrial applications are seriously restricted in the European Community, United Kingdom, United States of America, New Zealand, and Japan [36]. However, in many countries, including Venezuela, China, and India [4], legislation to control the use of such surfactants is inexistent or is not realistic. Therefore, it seems necessary to carry out studies to search for indigenous bacterial strains able to degrade $\mathrm{NPEO}_{x}$ to be used as possible bioremediation agents on contaminated natural environments.

This paper describes the isolation of five $\mathrm{NPEO}_{15}$ degrading bacterial strains. Two of them, Pseudomonas fluorescens (strain Yas2) and Klebsiella pneumoniae (strain Yas1), showed high capacity for using $\mathrm{NPEO}_{15}$ as sole carbon source. The degradation process was followed by viscometry of the previously used culturing media and measurement of the chemical and biological oxygen demands. To our knowledge, this is the first report of the $\mathrm{NPEO}_{x}$ degrading activity by Klebsiella sp.

\section{Materials and Methods}

2.1. Biological Samples. The bacterial strains were isolated from soil samples collected in the gardens of the Centro de Investigaciones Microbiológicas Aplicadas (CIMA-UC), Campus Bárbula, Carabobo, Venezuela. To our knowledge these gardens are not contaminated with $\mathrm{NPEO}_{15}$.

2.2. Culturing Broth. The bacteria were grown in a minimal mineral medium (MM) containing the followings salts $(\mathrm{p} / \mathrm{v})$ : $1 \% \mathrm{CuSO}_{4}, 0.1 \mathrm{~mL} ; 0.5 \% \mathrm{FeSO}_{4}, 2 \mathrm{~mL} ; 1 \% \mathrm{MgSO}_{4}, 0.2 \mathrm{~mL}$; $1 \% \mathrm{ZnSO}_{4}, 0.5 \mathrm{~mL} ; 0.7 \% \mathrm{NaCl}, 0.05 \mathrm{~mL} ; 0.1 \% \mathrm{NH}_{4} \mathrm{Cl}, 1.0 \mathrm{~mL}$; $0.8 \% \mathrm{NH}_{4} \mathrm{NO}_{3}, 0.125 \mathrm{~mL}$ and $1 \% \mathrm{CaCO}_{3}, 0.5 \mathrm{~mL}$, volume was adjusted to $1.0 \mathrm{~L}$ with $0.1 \mathrm{M}$ phosphate buffer at appropriated $\mathrm{pH}$ values, as it will be indicated further (MM medium). All salts were proanalysis quality and the ethoxylated nonylphenol $\left(\mathrm{NPEO}_{15}, \mathrm{MW} 880 \mathrm{~g} \mathrm{~mol}^{-1}\right.$ ) was kindly donated by Palma Products, CA Valencia, Venezuela.

2.3. Culture of Bacteria (MM/NPEO ${ }_{15}$ Medium). Soil samples $(100 \mathrm{~g})$ were suspended in MM medium $(250 \mathrm{~mL})$ in $500 \mathrm{~mL}$ flasks, at $\mathrm{pH} \mathrm{7.0,} \mathrm{in} \mathrm{aerobiosis,} \mathrm{and} \mathrm{appropriate}$ volumes of $\mathrm{NPEO}_{15}$ were added to reach final concentrations of $3 \% \mathrm{v} / \mathrm{v}$ and $30 \% \mathrm{v} / \mathrm{v}(0.0365$ and $0.365 \mathrm{M}$, resp.). The systems were incubated at room temperature $\left(22-25^{\circ} \mathrm{C}\right)$ under constant shaking during 45 days. Aliquots $(3 \mathrm{~mL})$, taken at different cultivation times, seeded in nutritive broth tubes and the bacterial growth was evaluated, after $24 \mathrm{~h}$ at $37^{\circ} \mathrm{C}$, by single visual inspection of turbidity. After streaking of the total bacterial population on nutritive agar plates, after $24-48 \mathrm{~h}$ at $37^{\circ} \mathrm{C}$, colonies were selected and assessed for growth in McConkey, Kliger's iron and oxidase media and finally the isolated colonies were stored in nutritive broth at $4^{\circ} \mathrm{C}$ until further use. The taxonomic identification was carried out by using the Analytical Profile Index (API) 20E and 20NE systems (bioMérieux sa, France).

2.4. Optimization of Bacterial Growth. The selected bacterial colonies were grown in $250 \mathrm{~mL}$ flasks containing $\mathrm{MM} / 3 \%$ $\mathrm{NPEO}_{15}$ medium $(50 \mathrm{~mL}), \mathrm{pH}$, in aerobiosis for $12 \mathrm{~h}$ at $27^{\circ} \mathrm{C}$, and then aliquots were submitted to different experimental protocols.

(I) To assess the purity and viability of the colonies, aliquots $(1 \mathrm{~mL})$ were added to the same medium $(150 \mathrm{~mL})$ at $27^{\circ} \mathrm{C}$ and the bacterial growth was assessed, at intervals of $3 \mathrm{~h}$, over a period of $9 \mathrm{~h}$, by measuring the absorption at $660 \mathrm{~nm}$ on a Spectronic Genesys II spectrophotometer. Simultaneously, aliquots $(1 \mathrm{~mL})$ were used, to prepare solutions by successive dilution that allowed determining the number of colony forming units per milliliter $\left(\mathrm{CFU} \mathrm{mL} \mathrm{m}^{-1}\right)$.

(II) The $\mathrm{MM} / 3 \% \mathrm{NPEO}_{15}$ medium was adjusted to different $\mathrm{pH}$ values $(7,8,8.5$ and 9$)$ and the bacterial growth was followed as indicated in protocol I.

(III) The MM medium was adjusted to 1,3 , and $5 \%$ $\mathrm{NPEO}_{15}$ concentrations $(0.0121,0.0365$, and $0.0605 \mathrm{M}$, resp.). The bacterial growth was followed as indicated in protocol I.

2.5. Chemical Oxygen Demand (COD). The assays were executed according to the open reflux method 5220B [37]. 


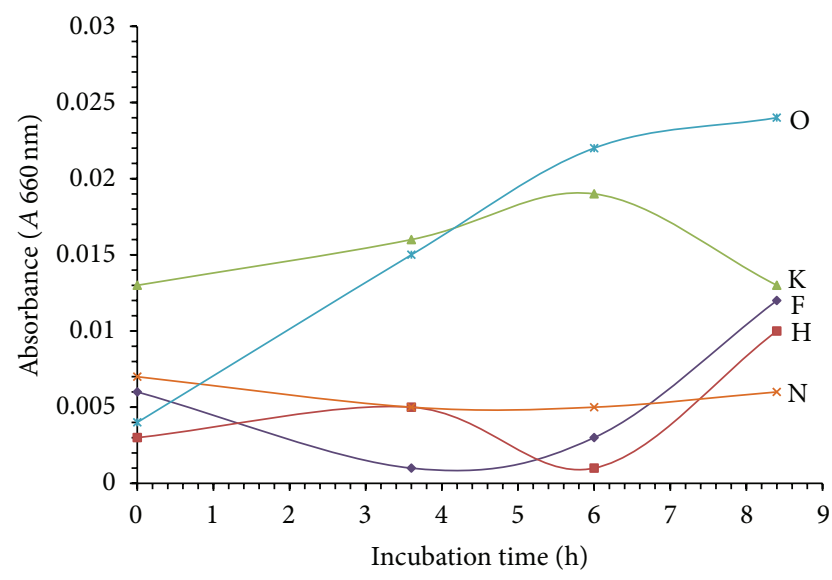

FIgURE 1: Growth of bacterial strains isolated from soil.

Bacterial strains were incubated for $24 \mathrm{~h}$ in $\mathrm{MM} / 1 \% \mathrm{NPEO}_{15}$ medium, $27^{\circ} \mathrm{C}$, and $\mathrm{pH} 8$, and bacterial growth was followed every $3 \mathrm{~h}$, at $660 \mathrm{~nm}$ absorbance. Aliquots were withdrawn after 0,6 , and $24 \mathrm{~h}$ incubations, and the samples were filtered through Millipore membranes $(0.45 \mu \mathrm{m}$ pore size) to obtain free bacterial filtrates (FBF) and submitted to analysis. A blank system (without bacterial inoculums) was also assayed.

2.6. Biological Oxygen Demand (BOD5). The assays were carried out according to the electrode membrane method 5210B [37]. After $24 \mathrm{~h}$ at $27^{\circ} \mathrm{C}, \mathrm{pH} 8$ in $\mathrm{MM} / 1 \% \mathrm{NPEO}_{15}$ medium, inoculums $(1 \mathrm{Ml})$ were incubated in the same medium and conditions. Aliquots were withdrawn after 6, 24, and $48 \mathrm{~h}$ incubation times and dilutions prepared in water $(300 \mathrm{~mL})$ were incubated for 5 days at $20^{\circ} \mathrm{C}$ in a dark and dry chamber. The oxygen was determined by an OAKTON DO 100.A electrode system. The value at zero time was also assayed.

2.7. Viscosity Studies. Volumes $(5 \mathrm{~mL})$ of bacterial cultures grown in $\mathrm{MM} / 5 \% \mathrm{NPEO}_{15}$ medium, $\mathrm{pH} 8$, at $27^{\circ} \mathrm{C}$ for $12 \mathrm{~h}$, were transferred to the same medium $(300 \mathrm{~mL})$ and aliquots were withdrawn at different times for one week at $25^{\circ} \mathrm{C}$. Immediately after the removal, the samples were filtered through Millipore membranes $(0.45 \mu \mathrm{m}$ pore size) to obtain the FBF and stored at $-20^{\circ} \mathrm{C}$ until further use. The viscosity changes were determined in a Cannon 50W404 Ostwalt viscometer at $25^{\circ} \mathrm{C}$ and densities in a $10 \mathrm{~mL}$ pycnometer. A calibration curve relating flow times (seconds) in the viscometer to $\mathrm{NPEO}_{15}$ concentrations $(\mathrm{mM})$ was obtained in order to determine the remaining $\mathrm{NPEO}_{15}$ concentrations. Values, at $25^{\circ} \mathrm{C}$, for water density $\left(0.99704 \mathrm{~g} \mathrm{~mL}^{-1}\right)$ and viscosity $\left(0.8904 \mathrm{~g} \mathrm{~cm}^{-1} \mathrm{~s}^{-1}\right.$, centipoises) were taken from Weast [38]. Relative viscosity values were calculated by the expression $\eta_{s}=\eta_{o} t_{s} \rho_{s} / t_{o} \rho_{o}$, where zero subscript refers to water and $s$ to $\mathrm{NPEO}_{15}$ aqueous solutions $[39,40]$.

\section{Results and Discussion}

3.1. Bacterial Colony Isolation and Taxonomic Identification. From the soil samples five indigenous bacterial colonies were isolated, of which strain $\mathrm{H}$ grew on $\mathrm{MM} / 3 \% \mathrm{NPEO}_{15}$ medium and the other four (strains $\mathrm{F}, \mathrm{K}, \mathrm{N}$, and $\mathrm{O}$ ) on $\mathrm{MM} / 30 \%$ $\mathrm{NPEO}_{15}$. Table 1 shows the morphological and biochemical characteristics of the isolated strains.

The bacterial growth on $\mathrm{MM} / 3 \% \mathrm{NPEO}_{15}$ medium, $\mathrm{pH}$ $7,27^{\circ} \mathrm{C}$ is shown in Figure 1. Strains $\mathrm{K}$ and $\mathrm{O}$ showed the highest growth rates; both grew without lag phase and the logarithmic phase was observed until $6 \mathrm{~h}$ incubation time. Because of this behavior both strains were chosen to perform subsequent experiments. According to the API identification system strains $\mathrm{K}$ and $\mathrm{O}$ were identified as Pseudomonas fluorescens and Klebsiella pneumonia and were named Yas2 and Yas1, respectively.

3.2. Bacterial Growth Conditions. The behavior of the bacterial strains at different $\mathrm{pH}$ values is described in Figure 2. Maximal growth rates were achieved at $\mathrm{pH} 8(0.04$ and 0.033 absorbance units), whereas the minimal growth was observed at $\mathrm{pH} 9(0.008$ and $0.01 \mathrm{au})$ after $6 \mathrm{~h}$ culturing time. These data correlated well with the $\mathrm{CFU} \mathrm{mL} \mathrm{m}^{-1}$ numbers at $6 \mathrm{~h}$ culture: $10^{6}-10^{7}$ and $10^{3}-10^{4} \mathrm{CFU} \mathrm{mL}{ }^{-1}$ at $\mathrm{pH} 8$ and 9 , respectively (data not shown).

In Figure 3 the bacterial growth patterns with respect to the $\mathrm{NPEO}_{15}$ concentration in the media are shown. Maximal (0.09 and $0.062 \mathrm{au})$ and minimal (0.019 and $0.012 \mathrm{au}$ ) growth values were achieved at $5 \%$ and $1 \% \mathrm{NPEO}_{15}$, respectively, at $9 \mathrm{~h}$ incubation times.

Usually, in the culture media of $1 \%$ and $3 \%$ the maximal growth was observed at $6 \mathrm{~h}$ incubation, and then it reached the stationary growth phase at $9 \mathrm{~h}$. The logarithmic growth phase persisted until $9 \mathrm{~h}$ for the $5 \% \mathrm{NPEO}_{15}$ system, and then the stationary phase disappeared. Finally, a mixture culture of Yas1/Yas2 in 1\% $\mathrm{NPEO}_{15}$ medium, $\mathrm{pH} 8$, showed a synergistic effect on the bacterial growth, reaching maximal values $(0.095 \mathrm{au})$ at $9 \mathrm{~h}$ incubations and $27^{\circ} \mathrm{C}$, which represents a stimulatory average factor close to 5.7 with respect to the individual bacterial cultures at $1 \% \mathrm{NPEO}_{15}$ medium (0.014 and $0.02 \mathrm{au}$ ); additionally, the lag phase was absent (see Figure 4). This stimulatory effect is probably due to $\mathrm{NPEO}_{x}$ cometabolism by the Yas1/Yas2 system, as it has been described for other bacterial consortiums [41].

3.3. Degradation of $\mathrm{NPEO}_{15}$ by Bacteria. The $\mathrm{NPEO}_{15}$ biodegradation was determined in FBF by following the flow time in a viscometer and by the chemical oxygen demand, also the biological oxygen demand was evaluated. Figure 5 shows the calibration curve that relates the molarity of $\mathrm{NPEO}_{15}$ solutions and their flow times in a viscometer. The data fit the equation $Y=226.9+0.9418 X\left(R^{2}=0.94\right)$ calculated by linear regression.

Tables 2 and 3 show the viscosity and density changes, flow times (s), molarity (M) of remaining $\mathrm{NPEO}_{15}$, and density $\left(\mathrm{g} \mathrm{L}^{-1}\right)$ and viscosity $\left(\mathrm{g} \mathrm{cm}^{-1} \mathrm{~s}^{-1}\right)$ of the FBF corresponding to different incubation times for both bacterial strains. A decrease in the FBF viscosity and density correlated well to the observed decrease of the determined flow times. From an initial value of $1.150 \mathrm{~g} \mathrm{~cm}^{-1} \mathrm{~s}^{-1}$ the viscosity was reduced to 0.8959 and 0.8490 for Yas1 and Yas2 systems, respectively. 
TABLE 1: Morphological and biochemical characteristics of bacterial strains isolated from soil.

\begin{tabular}{|c|c|c|c|c|c|}
\hline Strain & Morphology & Gram & MacConkey & $\begin{array}{l}\text { Kliger } \\
\text { iron's }\end{array}$ & Oxidase \\
\hline $\mathrm{F}$ & $\begin{array}{l}\text { Red colonies } \\
\text { Large and thin bacilli }\end{array}$ & Negative & Lactose+ & Glucose+ & - \\
\hline $\mathrm{H}$ & $\begin{array}{l}\text { Light yellow colonies } \\
\text { Large and thin bacilli }\end{array}$ & Negative & Lactose- & Glucose- & + \\
\hline $\begin{array}{l}\mathrm{K} \\
\text { Yas1 }\end{array}$ & $\begin{array}{l}\text { Dark yellow, mucous colonies } \\
\text { Small bacilli }\end{array}$ & Negative & Lactose+ & Glucose+ & - \\
\hline $\mathrm{N}$ & $\begin{array}{l}\text { Brown colonies } \\
\text { Small and thin bacilli }\end{array}$ & Negative & Lactose- & Glucose- & + \\
\hline $\begin{array}{l}\mathrm{O} \\
\text { Yas2 }\end{array}$ & $\begin{array}{l}\text { Ligth yellow colonies } \\
\text { Small bacilli }\end{array}$ & Negative & Lactose- & Glucose- & + \\
\hline
\end{tabular}

Signs indicate positive/negative fermentation or enzymatic activity.

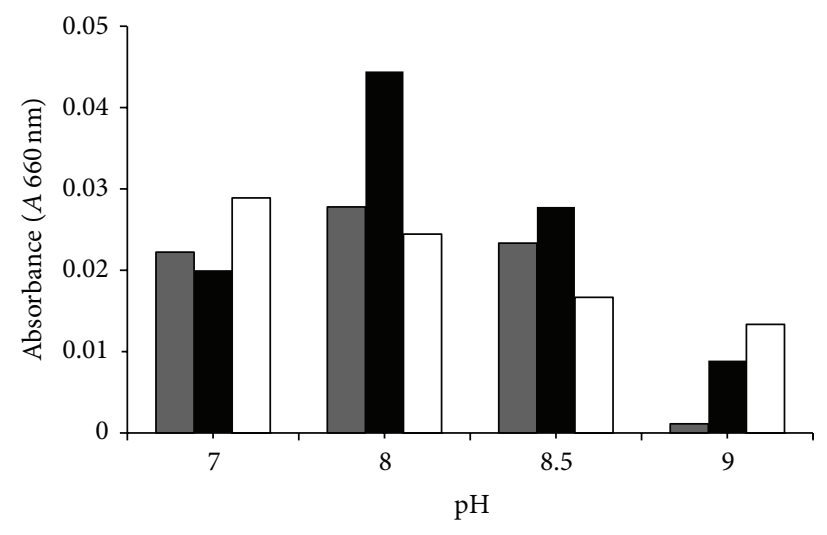

(a)

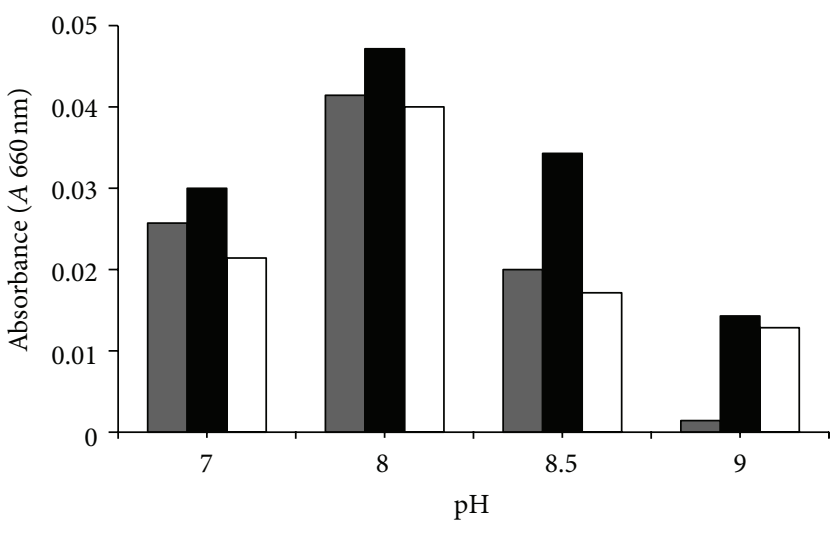

(b)

Figure 2: Bacterial growth on $3 \% \mathrm{NPEO}_{15}$ at different $\mathrm{pH}$ values. Gray, black, and white bars indicate bacterial growth at 3, 6, and $9 \mathrm{~h}$, respectively. (a) Klebsiella pneumoniae strain Yas1; (b) Pseudomonas fluorescens strain Yas2.

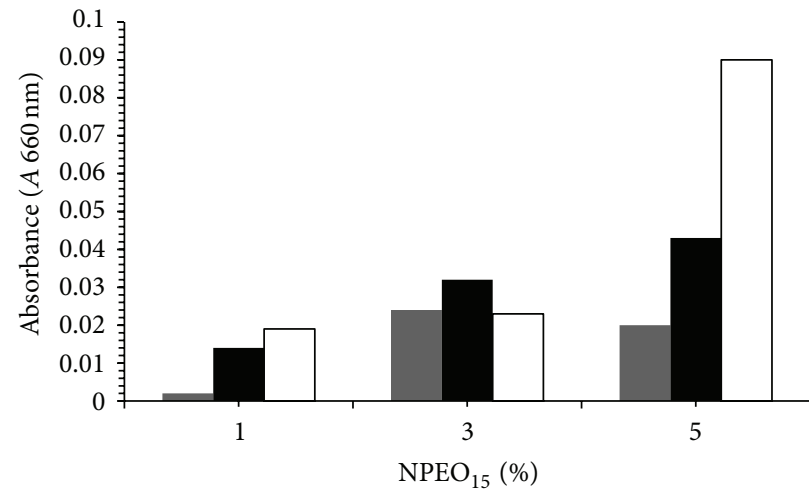

(a)

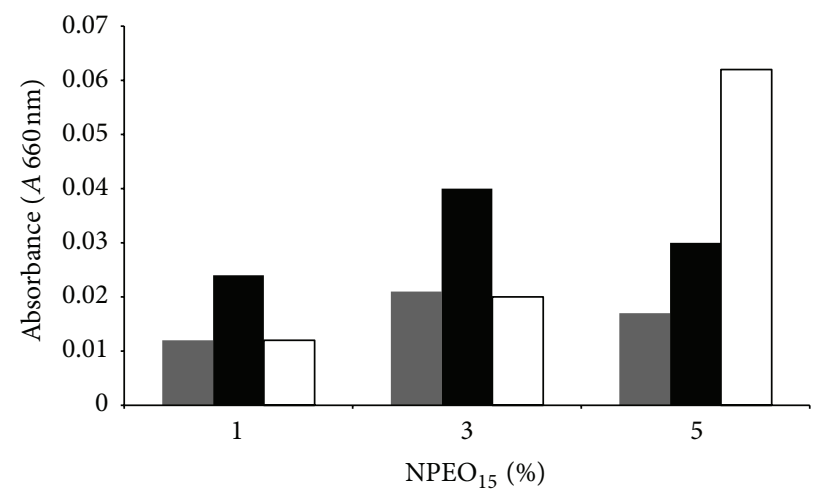

(b)

Figure 3: Bacterial growth at different $\mathrm{NPEO}_{15}$ concentrations. Grey, black, and white bars indicate bacterial growth at 3, 6, and $9 \mathrm{~h}$, respectively. (a) Klebsiella pneumoniae strain Yas1. (b) Pseudomonas fluorescens strain Yas2.

These facts indicated the cleavage of the $\mathrm{NPEO}_{15}$ to lower molecular weight species. On basis of these data Yas1 and Yas2 degraded $0.0392(0.0605-0.0213)$ and $0.0383 \mathrm{NPEO}_{15}$ moles $\mathrm{L}^{-1}(0.0605-0.0216)$ in 54.5 and $134 \mathrm{~h}$, respectively. The extension of the degradation process has been reported as temperature dependent $[6,42]$. In this study degradation was close to $65 \%$ at $27^{\circ} \mathrm{C}$; similar values have been reported by other authors [6, 40,41,43].

It was also observed that foam appearing at the beginning of the incubations decreased at late incubation times. At $71 \mathrm{~h}$ (Yas1) and $163 \mathrm{~h}$ (Yas2) incubations, foam had totally disappeared and simultaneously, viscosity increases were evident 
TABle 2: Physical chemical parameters of the $0.0605 \mathrm{M} \mathrm{NPEO}_{15}$ degradation by Klebsiella pneumoniae strain Yas1.

\begin{tabular}{lcccc}
\hline Incubation time $(\mathrm{h})$ & Flow time $(\mathrm{s})^{*}$ & Remaining NPEO $\left(\mathrm{moles} \mathrm{L}^{-1}\right)$ & Density $\left(\mathrm{g} \mathrm{L}^{-1}\right)^{* *}$ & ${\mathrm{Viscosity}\left(\mathrm{g} \mathrm{cm}^{-1} \mathrm{~s}^{-1}\right)}$ \\
\hline 0 & 283.9 & 0.0605 & $0.9287 \pm 0.0395^{\dagger}$ & 1.1500 \\
8.5 & $259.7 \pm 1.689^{\dagger}$ & 0.0348 & $0.9964 \pm 0.044$ & 0.9583 \\
22.5 & $273.6 \pm 1.376$ & 0.0495 & $0.9146 \pm 0.0049$ & 1.0831 \\
32.5 & $250.0 \pm 2.185$ & 0.0245 & $0.9140 \pm 0.0071$ & 0.9084 \\
49.5 & $256.0 \pm 1.260$ & 0.0308 & $0.9129 \pm 0.0058$ & 0.9296 \\
54.5 & $247.0 \pm 2.753$ & 0.0213 & $1.0137 \pm 0.039$ & 0.8959 \\
71.0 & $285.5 \pm 1.941$ & 0.0622 & 1.1479 & \\
\hline
\end{tabular}

${ }^{*}$ Flow time of the $\mathrm{FBF}$ in the viscometer at $25^{\circ} \mathrm{C}$, average of nine measurements. ${ }^{* *}$ Average of six measurements. ${ }^{\dagger}$ Standard deviation.

TABLE 3: Physical chemical parameters of the $0.0605 \mathrm{M} \mathrm{NPEO}_{15}$ degradation by Pseudomonas fluorescens strain Yas2.

\begin{tabular}{lcccc}
\hline Incubation time $(\mathrm{h})$ & Flow time $(\mathrm{s})^{*}$ & Remaining NPEO $\left(\mathrm{moles} \mathrm{L}^{-1}\right)$ & Density $\left(\mathrm{g} \mathrm{L}^{-1}\right)^{* *}$ & ${\mathrm{Viscosity}\left(\mathrm{g} \mathrm{cm}^{-1} \mathrm{~s}^{-1}\right)}$ \\
\hline 0 & 283.9 & 0.0605 & 1.0200 & 1.1500 \\
6.0 & $278.9 \pm 1.969^{\dagger}$ & 0.0552 & $1.0064 \pm 0.001^{\dagger}$ & 1.1152 \\
12.0 & $280.9 \pm 2.320$ & 0.0573 & $1.0141 \pm 0.0047$ & 1.1235 \\
36.0 & $270.6 \pm 1.056$ & 0.0464 & $0.9805 \pm 0.0132$ & 1.0903 \\
60.5 & $264.9 \pm 1.357$ & 0.0403 & $0.9098 \pm 0.0029$ & 1.0320 \\
71.5 & $261.6 \pm 1.069$ & 0.0368 & $0.9190 \pm 0.0053$ & 0.9456 \\
112.5 & $255.4 \pm 0.853$ & 0.0302 & $0.8714 \pm 0.0365$ & 0.9325 \\
117.5 & $251.3 \pm 0.506$ & 0.0259 & $0.8641 \pm 0.0216$ & 0.8700 \\
134.0 & $247.3 \pm 2.573$ & 0.0216 & $0.9855 \pm 0.0488$ & 0.8490 \\
163.0 & $285.9 \pm 1.354$ & 0.0626 & 1.1194 & \\
\hline
\end{tabular}

${ }^{*}$ Flow time of the $\mathrm{FBF}$ in the viscometer at $25^{\circ} \mathrm{C}$, average of six measurements. ${ }^{* *}$ Average of four measurements. ${ }^{\dagger}$ Standard deviation.

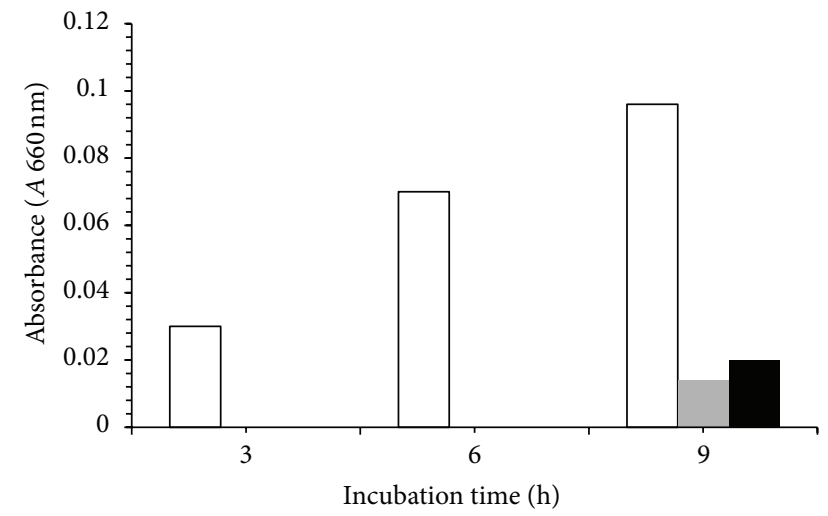

Figure 4: Growth of a mixture culture of Yas1/Yas2 on 1\% NPEO $_{15}$. Grey and Black colors correspond to the individual cultures of Yas1 and Yas2 respectively.

in both cultures. It is well known that several bacterial genera are able to produce viscous polymers (mucopolysaccharides, dextrans, proteins, poly- $\beta$-hydroxybutyrate, polyphosphates, and xanthans) as strategies to retain nutrients and water, as energy reserves and for defense purposes [44-48]. Another aspect for consideration is the observed viscosity changes with the incubation times; Yas1 decreased the viscosity from $1.15 \mathrm{~g} \mathrm{~cm}^{-1} \mathrm{~s}^{-1}$ to 0.8959 in $54.5 \mathrm{~h}$, a relative short time; at $8.5 \mathrm{~h}$ of incubation the viscosity fell, but it suddenly rose $(22.5 \mathrm{~h})$ to fall again at $32.5 \mathrm{~h}$ incubation. This apparent data dispersion could be due to the well-known mucogenic properties of the Klebsiella genus [44, 46, 47], which was also observed

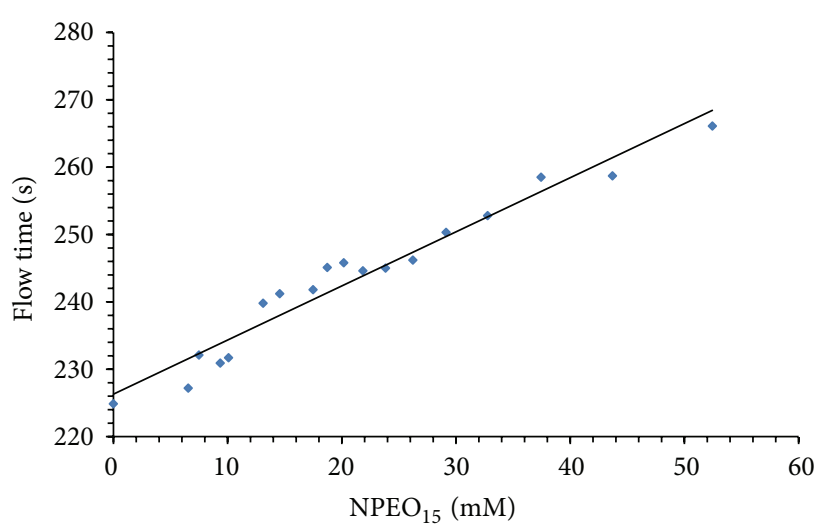

FIGURE 5: Calibration curve relating flow time to $\mathrm{NPEO}_{15}$ concentration. Each point represents the average of three determinations.

in this study (see Table 1). On the other hand, Yas2 changed the viscosity from 1.15 to $0.849 \mathrm{~g} \mathrm{~cm}^{-1} \mathrm{~s}^{-1}$, in $134 \mathrm{~h}$, a relative longer time, without abrupt changes. Thus, Yasl produced viscous materials at early and late incubation times, whereas Yas2 did it only at late times. Synthesis of dextrans and alginates by Klebsiella and Pseudomonas, respectively, has been reported [49-51]; therefore, viscometry studies to evaluate degradation of viscous substances seem to be inappropriate when the bacteria are capable of synthesizing viscous polymers during the whole incubation time, such as Klebsiella did. However, if the bacteria yield viscous molecules at relatively late times during the incubation, then the viscosity 


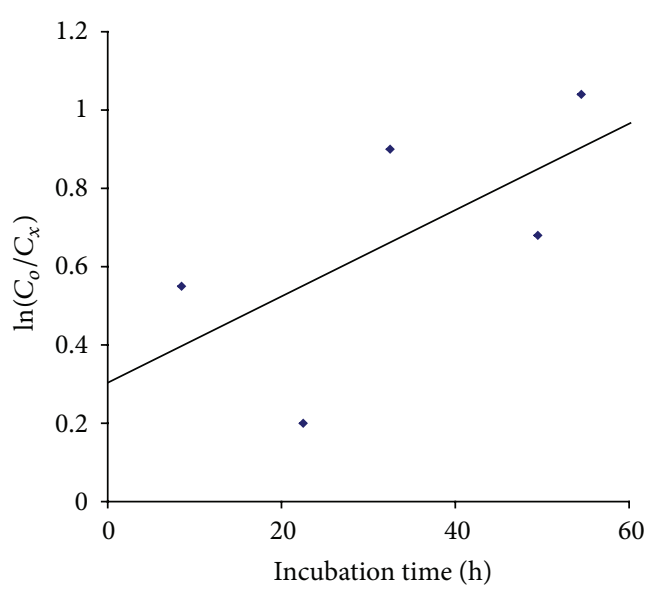

(a)

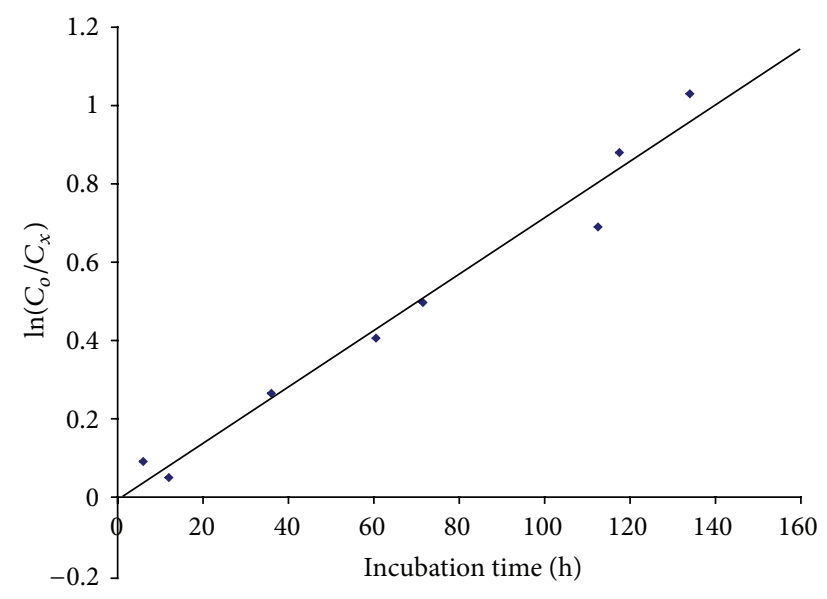

(b)

FIGURE 6: Kinetic order for the $\mathrm{NPEO}_{15}$ biodegradation reaction. (a) Klebsiella pneumoniae strain Yas1 $\left(Y=0.309+0.0109 X ; R^{2}=0.4028\right)$; (b) Pseudomonas fluorescens strain Yas2 $\left(Y=0.0072 X-0.0053 ; R^{2}=0.9728\right)$.

TABLE 4: Chemical oxygen demand.

\begin{tabular}{lcc}
\hline \multirow{2}{*}{ Incubation time $(\mathrm{h})$} & \multicolumn{2}{c}{ COD values $\left(\mathrm{mg} \mathrm{O}_{2} \mathrm{~L}^{-1}\right)$} \\
& Strain Yas1 & Strain Yas2 \\
\hline 0 & $20,230 \pm 4,303^{\dagger}$ & $20,230 \pm 4,303^{\dagger}$ \\
6 & $2,000 \pm 1,058$ & $3,333 \pm 1,890$ \\
24 & $666.4 \pm 462$ & $3.066 \pm 1.285$ \\
\hline
\end{tabular}

${ }^{\dagger}$ Standard deviation.

changes could be a useful, cheap, and rapid method to detect biodegradation of viscous xenobiotic polymers, as in the Pseudomonas system. Regardless of whether the bacteria degrade $\mathrm{NPEO}_{15}$ or the bacterial polymers, differences in degradation times displayed by the bacterial strains would imply that Yas1 cleaved chemical bonds near the aromatic ring in the $\mathrm{NPEO}_{15}$ molecule, producing low molecular weight species and causing a rapid change in the viscosity, whereas Yas2 seems to exert its action progressively on bonds near to the hydroxylated end of the surfactant ethoxylated chain, thus the decrease of the molecular mass was not as abrupt and the viscosity decrease should be slow. An alternative possibility is to assume Yas1 is a better enzyme producer. The reported data in Tables 2 and 3 allowed obtaining kinetic information about the $\mathrm{NPEO}_{15}$ biodegradation. Taking the initial $\left(C_{o}\right)$ and remaining $\left(C_{x}\right) \mathrm{NPEO}_{15}$ concentrations at different incubation times it was possible to determine the kinetic order for the $\mathrm{NPEO}_{15}$ biodegradation according to first- and second-order kinetic equations for a chemical reaction [39], also the kinetic rate constant $k$ and the half life time $\tau$ for the NPEO biotransformation were calculated.

Figure 6(b) shows the $\ln \left(C_{o} / C_{x}\right)$ versus $t$ plot corresponding to the Yas2 data (Table 3). The obtained straight line $\left(Y=0.0072 X-0.0053, R^{2}=0.9728\right)$ indicated the $\mathrm{NPEO}_{15}$ biodegradation obeyed first-order reaction kinetics; data from other laboratories indicated that $\mathrm{NPEO}_{1}$ and $\mathrm{NPEO}_{2}$ also obeyed the same order kinetics [32]. A similar analysis for the Yas1 system (Figure 6(a)) did not allow assigning any reaction order because of the viscous material
TABLE 5: Biological oxygen demand.

\begin{tabular}{lcc}
\hline \multirow{2}{*}{ Incubation time $(\mathrm{h})$} & \multicolumn{2}{c}{ BOD values $\left(\mathrm{mg} \mathrm{O}_{2} \mathrm{~L}^{-1}\right)$} \\
& Strain Yas1 & Strain Yas2 \\
\hline 0 & 8.675 & $14,000 \pm 5,515^{\dagger}$ \\
6 & $2,245 \pm 1,874^{\dagger}$ & $1,992 \pm 1,295$ \\
24 & $60.11 \pm 51.3$ & $67.8 \pm 46.9$ \\
48 & $5.26 \pm 4.12$ & $5.11 \pm 3.11$ \\
\hline${ }^{\dagger}$ Standard deviation. & &
\end{tabular}

synthesized at early and late time incubations by the Yas1 strain. The estimated values of the rate constant $k$ and time $\tau$ for Yas 2 were $0.0072 \mathrm{~h}^{-1}$ and $96.3 \mathrm{~h}$, respectively. For these calculations the corresponding data at $163 \mathrm{~h}$ were not considered because the observed viscosity increments were probably due to the synthesis of viscous bacterial polymers and not due to $\mathrm{NPEO}_{15}$ present in the media.

Although the maximal bacterial growth was obtained at $5 \% \mathrm{NPEO}_{15}$, the following experiments were executed at $1 \%$ $\mathrm{NPEO}_{15}$ because the principal aim of this study was to propose a satisfactory solution to the real environmental NPEO contamination which according to several reports should be less than $1 \mathrm{mg} \mathrm{L}^{-1}[23,52-55]$.

The chemical and biological oxygen demands, determined in broths previously used by microorganisms, are indirect measurements of the carbonaceous substrate degradation by a microbial population. Tables 4 and 5 shows the chemical oxygen demand (COD) and the biological oxygen demand (BOD) of both bacterial cultures in $\mathrm{MM} / 1 \% \mathrm{NPEO}_{15}$ medium, $\mathrm{pH} 8$ at different incubation times.

After $24 \mathrm{~h}$ incubation, the COD values decreased from an initial value of $20,230 \mathrm{mgO}_{2} \mathrm{~L}^{-1}$ (zero time) to 666 and $3,066 \mathrm{mgO}_{2} \mathrm{~L}^{-1}$, which represent 96 and $85 \% \mathrm{NPEO}_{15}$ degradation for Yas1 and Yas2 strains, respectively (see Table 4). These low COD values, representing 4 and $15 \%$ of the initial values, indicate that both bacterial strains can probably degrade $\mathrm{NPEO}_{15}$ and its low ethoxylated derivatives, including nonylphenol, as it has been reported for other bacterial 
strains $[6,26,43,56]$. The $\mathrm{BOD}_{5}$ data (Table 5) indicated that both bacterial strains consumed $99 \%(60.11 / 8,675$ and $67.8 / 14,000)$ and $99.9 \%(5.26 / 8,675$ and $5.11 / 14,000)$ of the available oxygen in 24 and $48 \mathrm{~h}$, respectively, which implies that the $\mathrm{NPEO}_{15}$ derivatives did not exert appreciable toxic effects on the bacterial strains and are biodegradable.

$\mathrm{NPEO}_{x}$ and its derivative degrading bacterial strains have been isolated from several natural environments and wastewater treatment plants [1, 5, 21, 30,57-59]. In this paper the reported data indicated that indigenous bacterial strains, isolated from soil, are able to use $\mathrm{NPEO}_{15}$ as the sole carbon source. Although the viscosity descent is indicative of bond cleavages in the $\mathrm{NPEO}_{15}$ molecule, it does not imply the use of the degradation products for sustaining the bacterial viability. However, the changes in the chemical and biological oxygen demands and the increments (viability) in the $\mathrm{CFU} \mathrm{mL} \mathrm{L}^{-1}$ number in $\mathrm{NPEO}_{15}$ complemented media indicate that Yas1 and Yas2 must use the $\mathrm{NPEO}_{15}$ degradation products to satisfy their metabolic requirements and support cellular division. P. fluorescens (Yas1) and K. pneumoniae (Yas2) thus appear to be useful biotechnological tools to bioremediate NPEO contaminated waters and soils.

\section{Conclusions}

Five bacterial strains, isolated from soil, grew on a minimal mineral medium supplemented with $\mathrm{NPEO}_{15}(0.0365 \mathrm{M}$ and $0.365 \mathrm{M})$ as the sole carbon source, being Pseudomonas fluorescens and Klebsiella pneumoniae the two most efficient $\mathrm{NPEO}_{15}$ degrading strains. The extent of $\mathrm{NPEO}_{15}$ degradation after $24-48 \mathrm{~h}$ incubations, evaluated by COD and $\mathrm{BOD}_{5}$ assays, was, $85-95 \%$ and $99.9 \%$ respectively. The kinetic rate constant $(k)$ and the half life time $(\tau)$ for the $\mathrm{NPEO}_{15}$ biotransformation by $P$. fluorescence were estimated to be $0.0072 \mathrm{~h}^{-1}$ and $96.3 \mathrm{~h}$, respectively, and the process followed first-order kinetics.

\section{References}

[1] M. A. Manzano-Quiones, J. A. P. Vargas-Machuca, D. SalesMrquez, and J. M. Quiroga-Alonso, "Cinética de biodegradacin de un nonilfenol polietoxilado en agua de ro," Ingeniería del Agua, vol. 5, pp. 27-35, 1998.

[2] A. Jiménez-González, S. Siles-Alvarado, and O. Monroy, "Biodegradation of octylphenol polyethoxylates by denitrification," Water Science and Technology, vol. 48, no. 6, pp. 165-170, 2003.

[3] R. Vzquez-Duhalt, F. Mrquez-Rocha, E. Ponce, A. F. Licea, and M. T. Liana, "Nonylphenol an integrated vision of a pollulant," Applied Ecology and Environmental Research, vol. 4, pp. 1-25, 2005.

[4] Z. Mao, X.-F. Zheng, Y.-Q. Zhang, X.-X. Tao, Y. Li, and W. Wang, "Occurrence and biodegradation of nonylphenol in the environment," International Journal of Molecular Sciences, vol. 13, no. 1, pp. 491-505, 2012.

[5] F. L. P. Gabriel, W. Giger, K. Guenther, and H.-P. E. Kohler, "Differential degradation of nonylphenol isomers by Sphingomonas xenophaga Bayram," Applied and Environmental Microbiology, vol. 71, no. 3, pp. 1123-1129, 2005.
[6] G.-G. Ying, "Fate, behavior and effects of surfactants and their degradation products in the environment," Environment International, vol. 32, no. 3, pp. 417-431, 2006.

[7] T. Tanghe, G. Devriese, and W. Verstraete, "Nonylphenol degradation in lab scale activated sludge units is temperature dependent," Water Research, vol. 32, no. 10, pp. 2889-2896, 1998.

[8] D. M. John and G. F. White, "Mechanism for biotransformation of nonylphenol polyethoxylates to xenoestrogens in Pseudomonas putida," Journal of Bacteriology, vol. 180, no. 17, pp. 4332-4338, 1998.

[9] G. Correa-Reyes, M. T. Viana, F. J. Marquez-Rocha, A. F. Licea, E. Ponce, and R. Vazquez-Duhalt, "Nonylphenol algal bioaccumulation and its effect through the trophic chain," Chemosphere, vol. 68, no. 4, pp. 662-670, 2007.

[10] A. Soares, B. Guieysse, B. Jefferson, E. Cartmell, and J. N. Lester, "Nonylphenol in the environment: a critical review on occurrence, fate, toxicity and treatment in wastewaters," Environment International, vol. 34, no. 7, pp. 1033-1049, 2008.

[11] W. Giger, P. H. Brunner, and C. Schaffner, "4-Nonylphenol in sewage sludge: accumulation of toxic metabolites from nonionic surfactants," Science, vol. 225, no. 4662, pp. 623-625, 1984.

[12] P. Voogt, O. Kwast, R. Hendriks, and N. Jonkers, "Alkylphenol ethoxylates and their degradation products in abiotic and biological samples from the environment," Analusis, vol. 28, no. 9, pp. 776-782, 2000.

[13] T. Toyooka, T. Kubota, and Y. Ibuki, "Nonylphenol polyethoxylates induce phosphorylation of histone H2AX," Mutation Research, vol. 741, no. 1-2, pp. 57-64, 2012.

[14] A. Marcomini, B. Pavoni, A. Sfriso, and A. A. Orio, "Persistent metabolites of alkylphenol polyethoxylates in the marine environment," Marine Chemistry, vol. 29, no. C, pp. 307-323, 1990.

[15] M. Ahel, J. McEvoy, and B. W. Giger, "Bioaccumulation of the lipophilic metabolites of nonionic surfactants in freshwater organisms," Environmental Pollution, vol. 79, no. 3, pp. 243-248, 1993.

[16] F. I. M. Adam and Z. M. El-Ashry, "Evaluation of genotoxicity of 4-n-nonylphenol using Vicia fabal L," Journal of Biological Sciences, vol. 10, no. 4, pp. 368-372, 2010.

[17] S. Frassinetti, C. Barberio, L. Caltavuturo, F. Fava, and D. Di Gioia, "Genotoxicity of 4-nonylphenol and nonylphenol ethoxylate mixtures by the use of Saccharomyces cerevisiae D7 mutation assay and use of this text to evaluate the efficiency of biodegradation treatments," Ecotoxicology and Environmental Safety, vol. 74, no. 3, pp. 253-258, 2011.

[18] N. F. Y. Tam, P. Wang, Q. T. Gao, and Y. S. Wong, "Toxicity of waterborne persistent organic pollulants on green microalgae," in 5th International Scientific Conference on Water, Climate and Environment (BALWOIS '12), Ohrid, Republic of Macedonia, 2012.

[19] A. E. D. H. Sayed, S. S. A. Hakeem, U. M. Mahmoud, and I. A. Mekkawy, "4 nonylphenol induced morphological and histopathological malformation in Bufo regularis tadpoles," Global Advanced Research Journal of Environmental Science and Toxicology, vol. 1, pp. 143-151, 2012.

[20] Ö. Karahan, T. Olmez-Hanci, I. Arslan-Alaton, and D. Orhon, "Modelling biodegradation of nonylphenol ethoxylate in acclimated and non-acclimated microbial cultures," Bioresource Technology, vol. 101, no. 21, pp. 8058-8066, 2010.

[21] P. L. Ferguson and B. J. Brownawell, "Degradation of nonylphenolethoxylates in estuarium sediment under aerobic and anaerobic conditions," Environmental Toxicology and Chemistry, vol. 22, pp. 1189-1199, 2003. 
[22] J. Lu, Y. He, J. Wu, and Q. Jin, "Aerobic and anaerobic biodegradation of nonylphenol ethoxylates in estuary sediment of Yangtze River, China," Environmental Geology, vol. 57, no. 1, pp. $1-8,2009$.

[23] T. Tanghe, W. Dhooge, and W. Verstraete, "Isolation of a bacterial strain able to degrade branched nonylphenol," Applied and Environmental Microbiology, vol. 65, no. 2, pp. 746-751, 1999.

[24] A. L. F. Andrade-Ribeiro A, A. Pacheco-Ferreira, C. L. Nbrega da Cunha, and A. S. Mendes-Kling, "Disruptores endocrinos: potencial problema para la salud pblica y medio ambiente," Revista Biomédica, vol. 17, pp. 146-150, 2006.

[25] H. Maki, N. Masuda, Y. Fujiwara, M. Ike, and M. Fujita, "Degradation of alkylphenol ethoxylates by Pseudomonas sp. strain TR01," Applied and Environmental Microbiology, vol. 60, no. 7, pp. 2265-2271, 1994.

[26] X. Liu, A. Tani, K. Kimbara, and F. Kawai, "Metabolic pathway of xenoestrogenic short ethoxy chain-nonylphenol to nonylphenol by aerobic bacteria, Ensifer sp. strain AS08 and Pseudomonas sp. strain AS90," Applied Microbiology and Biotechnology, vol. 72, no. 3, pp. 552-559, 2006.

[27] X. Gu, Y. Zhang, J. Zhang et al., "Isolation of phylogenetically diverse nonylphenol ethoxylate-degrading bacteria and characterization of their corresponding biotransformation pathways," Chemosphere, vol. 80, no. 3, pp. 216-222, 2010.

[28] X. Gu, Y. Zhang, J. Zhang, M. Yang, H. Takaki, and Y. Kamala, "Degradation behaviors of nonylphenolethoxylates by isolated bacteria using improved isolation method," Journal of Environmental Sciences, vol. 20, pp. 1025-1027, 2008.

[29] E. J. McAdam, J. P. Bagnall, A. Soares et al., "Fate of alkylphenolic compounds during activated sludge treatment: impact of loading and organic composition," Environmental Science and Technology, vol. 45, no. 1, pp. 248-254, 2011.

[30] P. Wang, X.-H. Nong, and J.-H. Ge, "Aerobic biodegradation of nonylphenol ethoxylates in shaking-flask test," Electronic Journal of Biotechnology, vol. 14, no. 4, p. 1, 2011.

[31] C. G. Naylor, J. B. Williams, P. T. Varineau et al., "Biodegradation of the ${ }^{14} \mathrm{C}$ ring labeled nonylphenolethoxylates in activated sludge and in river water," in Proceedings of 19th Annual Meeting of the Society of Environmental Toxicology and Chemistry, Charlotte, NC, USA, November 1998.

[32] Y.-S. Qiao, J. Zhang, M. Yang, Y. Zhang, and D.-Y. Xu, "Degradation of nonylphenol and short chain nonylphenol polyethoxylates in soil," Huang Jing Ke Xue, vol. 29, no. 4, pp. 869-873, 2008.

[33] D. Di Gioia, A. Michelles, M. Pierini, S. Bogialli, F. Fava, and C. Barberio, "Selection and characterization of aerobic bacteria capable of degrading commercial mixtures of low-ethoxylated nonylphenols," Journal of Applied Microbiology, vol. 104, no. 1, pp. 231-242, 2008.

[34] N. N. Tuan, H.-C. Hsieh, Y.-W. Lin, and S.-L. Huang, "Analysis of bacterial degradation pathways for long-chain alkylphenols involving phenol hydroxylase, alkylphenol monooxygenase and catechol dioxygenase genes," Bioresource Technology, vol. 102, no. 5, pp. 4232-4240, 2011.

[35] G. Yang, Y. Zhang, and Y. Bai, "Purification and characterization of a nonylphenol (NP)-degrading enzyme from Bacillus cereus. Frankland," Chinese Journal of Chemical Engineering, vol. 19, no. 4, pp. 644-648, 2011.

[36] L. A. Tremblay, M. Sterwart, B. M. Peake, and J. B. Gadd, "Review of the risks of emerging organic contaminants and potential impacts to Hawke's Bay," Tech. Rep. no. 1973, Cawthron Institute, Nelson, New Zealand, 2011.
[37] Standard Methods for the Examination of Water and Wastewater, APHA, AWWA, WEF, Washington, DC, USA, 20th edition, 1998.

[38] R. C. Weast, Handbook of Chemistry and Physics, CRC Press, Boca Raton, Fla, USA, 68th edition, 1987.

[39] G. W. Castellan, Fisicoqumica, Segunda Edicin, Addison-Wesley, Wilmington, NC, USA, S. A. Iberoamericana, Ed, 1987.

[40] K. E. van Holde, Physical Biochemistry, Prentice-Hall, Englewood Cliffs, NJ, USA, 1971.

[41] W. Song, K. S. Lim, D. U. Yu et al., "Isolation of a nonylphenoldegrading microbial consortium," Korean Journal of Fisheries and Aquatic Sciences, vol. 44, pp. 325-331, 2011.

[42] M. A. Manzano, J. A. Perales, D. Sales, and J. M. Quiroga, "The effect of temperature on the biodegradation of a nonylphenol polyethoxylate in river water," Water Research, vol. 33, no. 11, pp. 2593-2600, 1999.

[43] Y. Xie, T. Zhu, X. Liu, H. Liu, and J. Han, "Degradation of nonylphenol polyethoxylates and its microflora structure in an anoxin-oxic activated sludge process," Adv Mat Res, vol. 610613, pp. 331-336, 2013.

[44] J. G. Holt, N. R. Krieg, P. H. A. Sneath, J. T. Staley, and S. T. Williams, Bergey's Manual of Determinative Bacteriology, Lippincott, William \& Wilkins, Baltimore, Md, USA, 9th edition, 1994.

[45] M. T. Madigan, J. M. Martinko, Parker, and J. Brock, Biologa De Los Microorganismos, Pearson Educacin, Madrid, España, 10th ed edition, 2004.

[46] J. McFaddin, Pruebas Bioqumicas Para La Identificacin De Bacterias De Importancia Clnica, Editorial Medica Panamericana, Buenos Aires, Argentina, 3rd edition, 2004.

[47] B. A. Forbes, D. F. Sahm, and A. S. Wissfeld, Bailey and Scott Diagnstico Microbiolgico, Editorial Medica Panamericana, Buenos Aires, Argentina, 11st edition, 2004.

[48] B. Vu, M. Chen, R. J. Crawford, and E. P. Ivanova, "Bacterial extracellular polysaccharides involved in biofilm formation," Molecules, vol. 14, no. 7, pp. 2535-2554, 2009.

[49] J. Wingender, T. R. Neu, and H. C. Flemming, "What are bacterial extracellular polymeric substances," in Microbial Extracellular Polymeric Substances: Characterization, Structure and Function, J. Wingender, T. R. Neu, and H. C. Fleming, Eds., pp. 1-19, Spring, Berlin, Germany, 1999.

[50] J. Bu'lock and B. J. Kristiansen, in Biotecnologa Bsica, Acribia, Zaragoza, España, 1991.

[51] L. Feng, X. Li, G. Du, and J. Chen, "Characterization and fouling properties of exopolysaccharide produced by Klebsiella oxytoca," Bioresource Technology, vol. 100, no. 13, pp. 3387-3394, 2009.

[52] P. L. Ferguson, C. R. Iden, and B. J. Brownawell, "Distribution and fate of neutral alkylphenol ethoxylate metabolites in a sewage-impacted urban estuary," Environmental Science and Technology, vol. 35, no. 12, pp. 2428-2435, 2001.

[53] K. Komori, Y. Okayasu, M. Yasojima, Y. Suzuki, and H. Tanaka, "Occurrence of nonylphenol, nonylphenol ethoxylate surfactants and nonylphenol carboxylic acids in wastewater in Japan," Water Science and Technology, vol. 53, no. 11, pp. 27-33, 2006.

[54] R. L. Spehar, L. T. Brooke, T. P. Markee, and M. D. Kahl, "Comparative toxicity and bioconcentration of nonylphenol in freshwater organisms," Environmental Toxicology and Chemistry, vol. 29, no. 9, pp. 2104-2111, 2010.

[55] F. He, L. Niu, O. Aya, S. Wang, and L. Wang, "Ocurrence and fate of nonylphenol ethoxylates and their derivatives in Nansi 
Lake environments, China," Water Environment Research, vol. 85, pp. 27-34, 2013.

[56] L. Salvadori, D. Di Gioia, F. Fava, and C. Barberio, "Degradation of low-ethoxylated nonylphenols by a Stenotrophomonas strain and development of new phylogenetic probes for Stenotrophomonas spp. detection," Current Microbiology, vol. 52, no. 1, pp. 13-20, 2006.

[57] X. Peng, Z. Wang, B. Mai et al., "Temporal trends of nonylphenol and bisphenol A contamination in the Pearl River Estuary and the adjacent South China Sea recorded by dated sedimentary cores," Science of the Total Environment, vol. 384, no. 1-3, pp. 393-400, 2007.

[58] F. Li, J. Tsumori, Y. Suzuki, and H. Tanaka, "Vertical distribution of nonylphenol ethoxylates and their derivatives in sediments of a freshwater reservoir," Water, Air, and Soil Pollution, vol. 189, no. 1-4, pp. 265-277, 2008.

[59] D. U. Yu, "Isolation and characterization of nonylplhenol degrading bacteria," Fisheries and Aquatic Sciences, vol. 15, pp. 9197, 2011. 

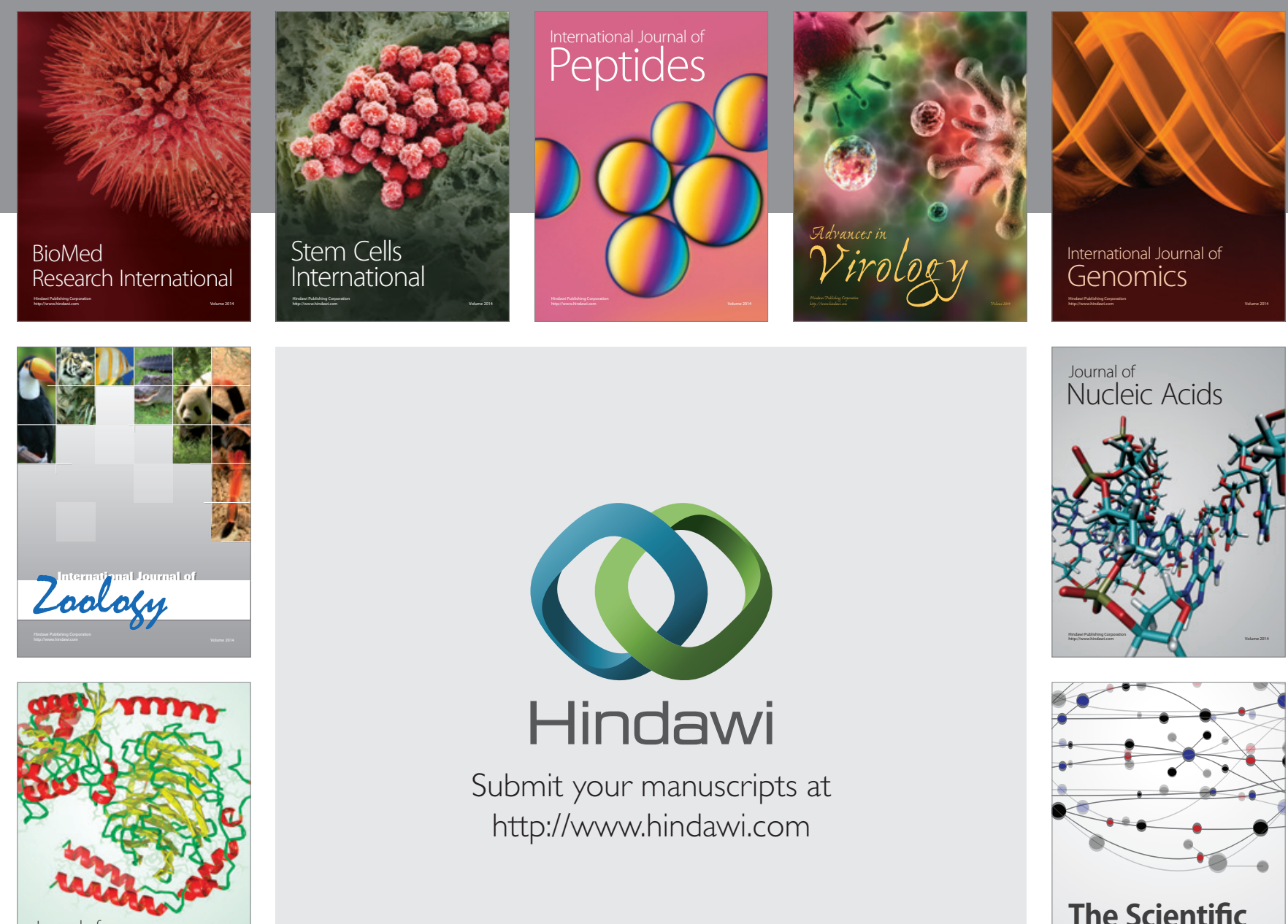

Submit your manuscripts at

http://www.hindawi.com

Journal of
Signal Transduction
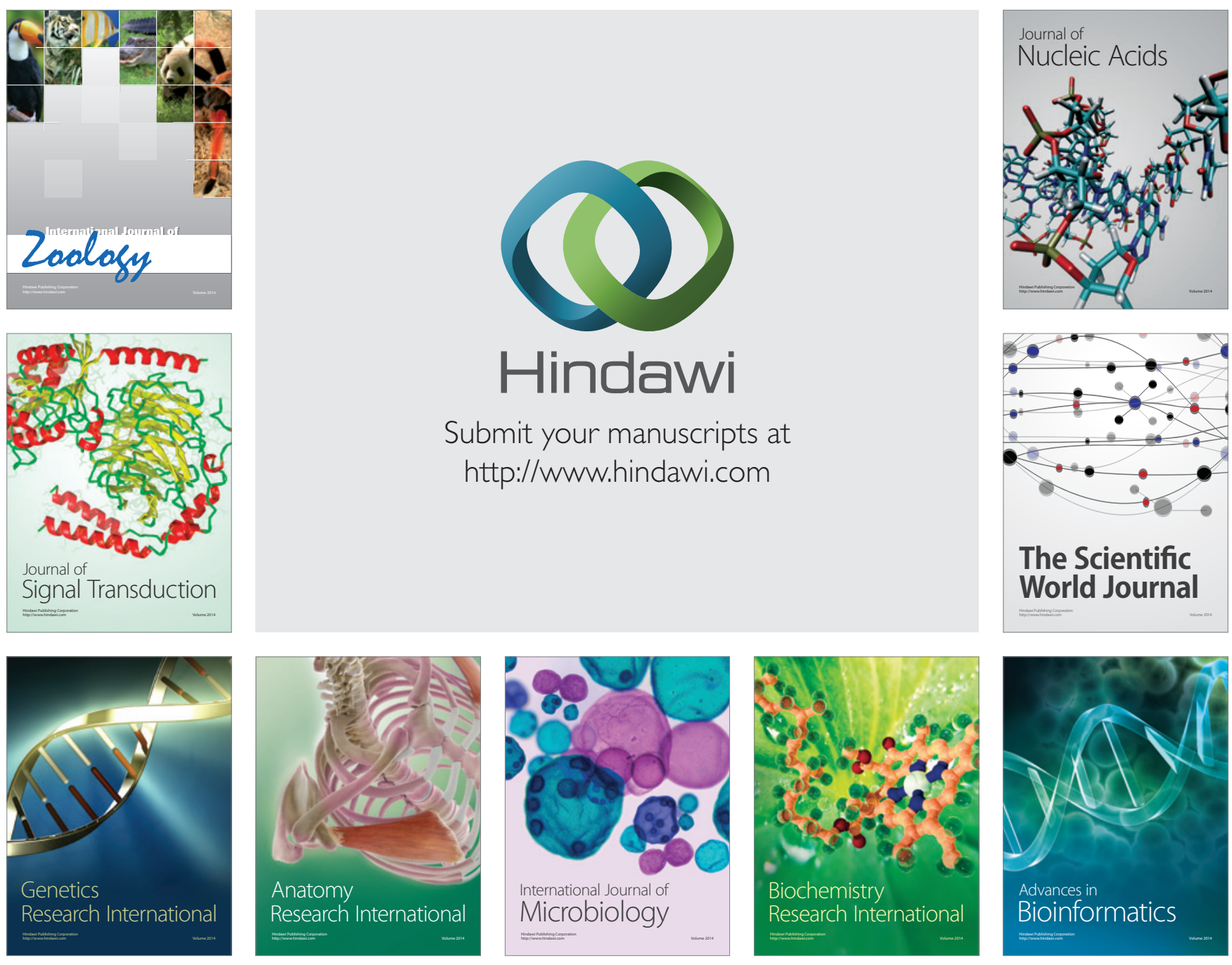

The Scientific World Journal
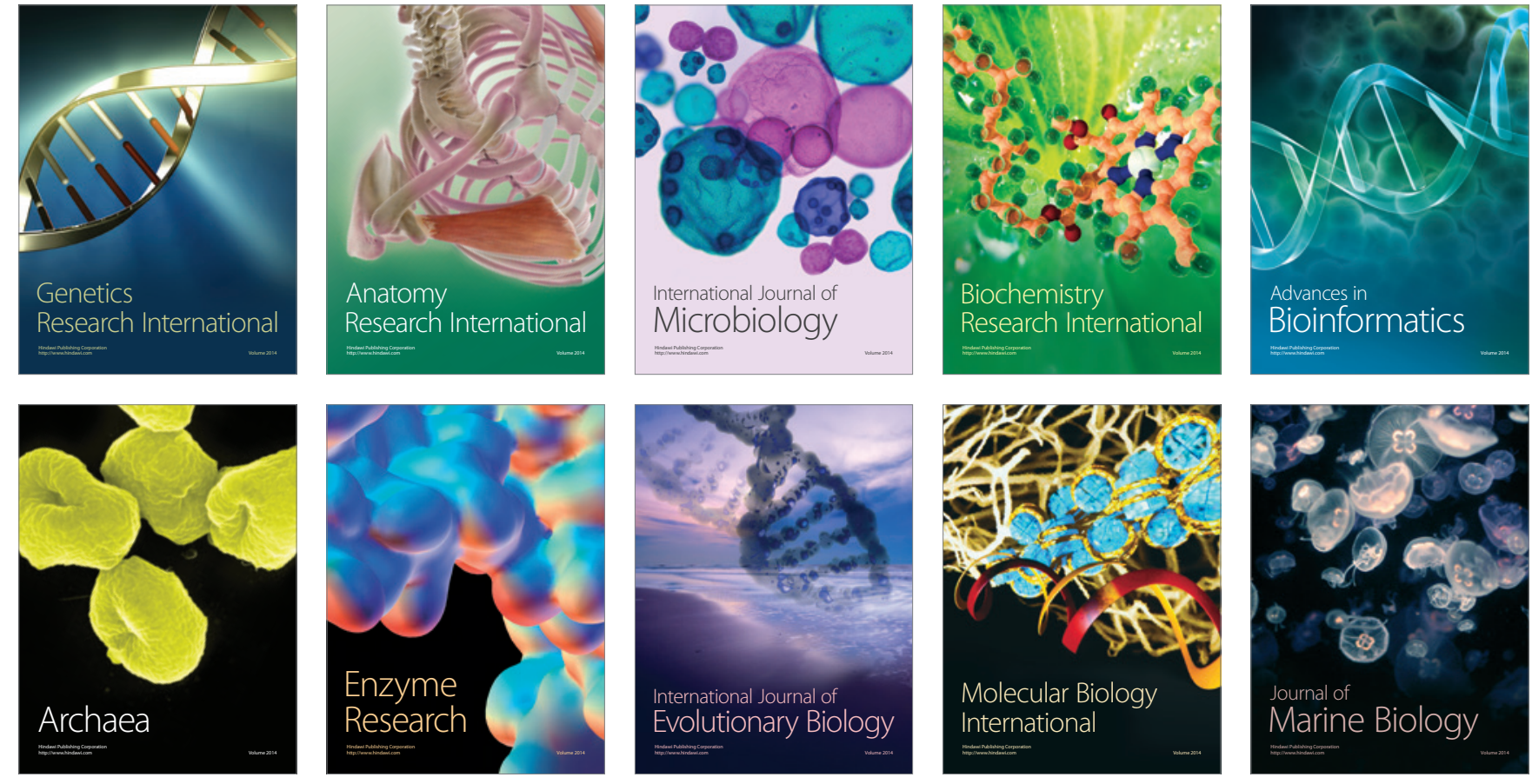